times when this may be urgently required. 'Clinical Nutrition' must therefore be welcomed for assembling so much valuable data in a form that makes it available for quick reference. The authors describe the various diets used in clinical work and provide chapters on specific treatments, each of which is written by an expert in his own field. They remind us also that the therapeutic diet should be a modification of the normal diet based on natural foods which are available to the particular patient, allowing for seasonal and environmental variations.

Chapters are also included on dietary and medical history, clinical manifestations of malnutrition, principles of therapy, dietotherapy, treatment of various types of obesity, relation of nutrition to health and its effects upon growth, nutrition in industrial medicine and the effects of low nutrient intake upon efficiency.

The nutritional requirements in health and disease are given and there is an appendix containing a selection of dietary patterns which, allowing for certain present limitations in this country, should be of great assistance. Tables giving the nutritional values of over 250 common foods are presented.

Althogether this is a book of merit and one to be warmly recommended.

R.M.S.

\section{MANSON'S TROPICAL DISEASES}

Edited by Sir Philip H. Manson Bahr, C.M.G., D.S.O., M.A., M.D., D.T.M.\&H., F.R.C.P. 1 3 th Edition. Pp. xiv + I 136 , with 26 plates and 412 figures. London: Cassell \& Co. 1950. $45 \mathrm{~s}$.

The first edition of ' Manson's Tropical Diseases' was published 52 years ago and its growth in size from then has been steadily progressive, apart from two rapid increases, the first in 1921 under the first able editorship of Manson's son-in-law, Sir Philip Manson Bahr, and now the r 3 th edition appears under the same distinguished name. These sudden increases in size reflect the accumulated knowledge gained in the two world wars.

In no branch of medicine has the intensive applied research due to the war yielded such dividends; the 'sulpha' drugs in dysentery, antibiotics such as chloromycetin in typhus and typhoid have revolutionized treatment. The introduction of potent new antimalarial drugs both for cure and prophylaxis, persistent insecticides such as D.D.T. and Gammexane, insect repellents such as dimethyl-phthalate have altered the conditions of life in the tropics. Our greatly increased knowledge of the vitamin deficiencies, a knowledge only gained at the cost of intense human suffering in the jungles of Burma and in P.O.W. camps in the Far East should, if world conditions permit, lead to their final abolition.

The introduction of potent oral drugs such as miracil in schistosomiasis, hetrazan in filariasis and sulphone and its derivatives in leprosy have provide the worker in the tropics with easily administere remedies which can be used on a large scale, both curatively and prophylactically without necessitating hospitalization of the patient.

The editor is to be congratulated on the successfud completion of this herculean task of bringing the edition up to date; this is the best 'Manson $\overline{\text { '? }}$ ' ever, and by saying that, it is synonymous wit saying that it is the best one volume work on tropic medicine in the world. With such a feast provideक्षै one hates to ask for more but a list of new references added between the I2th and the inevitable I4th edition would be a boon to the isolated worker the tropics.

\section{A SYNOPSIS OF MEDICINE}

By Sir HENRY Tidy, K.B.E., M.A., M.D., F.R.C.ळ 9th Edition. Pp. $x x+$ 1243. Bristol: John Wright \& Sons. London: Simpkin Marshales r 949 . 3os.

For the past 30 years Tidy's ' Synopsis of Medicine' has been a sine qua non to countless. students. For the final year, when so much has to be covered, there is no better book of reference? and when examinations have been safely negotiate how many men have packed it up with, perha्ps Pye's ' Surgical Handicraft' for their first locism

In this, its ninth edition, Sir Henry has manafeg to include a vast amount of new material, but dint of careful revision and pruning has enlarged the text by only four pages. As a sound basis for the student's reference there can be no questio that its I roo pages contain an enormous amount of pithy knowledge, excellently arranged and indexed in most handy form. It is strongly recommended and will undoubtedly more than uphold the reputation so deservedly gained by its predecessors?

\section{A SYNOPSIS OF OBSTETRICS AND GYNAECOLOGY}

By Aleck W. Bourne, M.A., M.B., B.Ch., F.R.C.S roth Edition. Pp. vii +530 , with 167 illustras tions. Bristol : John Wright \& Sons, Ltd I 949. 2 Is.

This very useful and comprehensive book fo을 the non-specialist student has been thoroughly rep vised in the fourth edition. In the preface the author says that he has omitted many out-dated ideas and methods but kept in mind the demands of examiners. Advances in knowledge have been in corporated and, generally speaking, it is thoroughlwo up to date.

Or the whole this is an excellent book, both for students and general practitioners. Differences of opinion naturally mean that few will agree wites every statemient but differing opinions have been mentioned where possible, and generally a mediump way has been advised in treatment. In a book of 
this type there is not room for great detail and one might have liked, for instance, to see more stress laid on the frequency of ante-natal examinations in the latter half of pregnancy, some reference to the teaching of relaxation in preparation for childbirth, and some other obstetric points but, on the whole, the book is very comprehensive. The use of pyridoxine and the anti-histamine drugs in hyperemesis gravidaum is omitted and so is a description of haemorrhagic disease of the newborn.

The gynaecological section is perhaps better than the obstetric and the method of taking gynaecological symptoms and setting out their causes, investigation and treatment is excellent. Probably in no other book can the harassed practitioner so quickly find a concise and comprehensive guide when faced with a patient presenting a symptom such as leucorrhoea, pruritus vulvae or sterility.

The lay-out of this book is, in fact, its chief recommendation. The clear headings, concise notes on important facts and theories, complete differential diagnosis and definite advice as to treatment make it a most excellent book of reference. Very little is omitted, perhaps in some sections almost too much has been included, but it is difficult to draw a line between essential and non-essential information, and, generally speaking, the knowledge of theories of causation in obstetrics and gynaecology is essential if examinations are to be passed.

Not only students but hospital residents and general practitioners will find this book invaluable. As the author says, its main purpose is for quick revision of a subject previously or simultaneously studied in a larger text book, but many busy practitioners find such a concise approach to a subject of much more value than the more lengthy and sometimes confusing detail of conflicting opinions found in the larger works, and will therefore find this book of greater service.

\section{EYE SURGERY}

By H. B. Stallard, M.B.E., M.A., M.D., F.R.C.S. 2nd Edition. Pp. xiii + 667 , with 550 illustrations. Bristol: John Wright \& Sons. 1950. £2 I2s. 6d.

The appearance of a second edition of this book within four years of the first is itself evidence of its value to students of ophthalmic surgery.

Whilst the individual character of the work, with its advocacy and detailed description of the techniques employed by the author and its emphasis on traumatic and reconstructive surgery has been retained, a number of valuable additions have been made. These concern, in the main, such surgical methods as scleral resection, gonitomy and keratoplasty and include also a description of the operation of basal iridencleisis which the author has recently introduced for glaucoma.

Useful paragraphs on the employment, as adjuncts to surgery, of amniotic membrane, fibrinogen, thrombin, penicillin and sterile air $z$ appear in appropriate sections. The text is notably $\stackrel{\mathbb{Q}}{\complement}$ aided by the addition of some 200 new illustrations. $c$ H.E.H.

\section{THE LAW AND ETHICS OF DENTAL PRACTICE}

By R. W. DURAND, M.R.C.S., L.R.C.P., and $\mathbb{\Phi}$ D. Morgan, L.D.S. Pp. vii +98 . London : English Universities Press, Ltd. I950. 7s. 6d.

Into this small volume the authors have compressed adequately the law and ethics of dental practice affecting the dentist in his relationship with his patients, his colleagues and his employees.

This field has aldready been covered by Edward Samson and S. L. Drummond-Jackson as far as private practice is concerned and the book would have been rendered much more valuable and far more attractive to those dentists, comprising ninetenths of the profession, who practise under the Dental Regulations of the National Health Service Act, if some space had been devoted to explaining their contractual obligations to their State patients and to their Local Executive Councils under the regulations.

This is the more to be regretted as one of the authors is admirably fitted to perform this task as he has intimate knowledge both of the practB tioner's difficulties and the Ministry's requirement

\section{A HISTOLOGY OF THE BODY TISSUES}

By Margaret Gillison. Pp. xiv + 220, with 103 illustrations. Edinburgh : E. \& S. Livingstone. 1950. I5s.

This little book describes most of the types of $\overrightarrow{\vec{O}}$ tissue in the human body and gives some account of their function and the kinds of way they are built into organs. Its author is lecturer in physiology at the I. M. Marsh College of Physical Education, Liverpool, and the book is aimed at medical auxiliaries such as physiotherapists.

It would serve also very well as an introduction to the background of their subject for histological technicians in training, for whom bigger books on histology are quite unsuited. The author's own illustrations are admirable.

B.L.

\section{GERMAN-ENGLISH MEDICAL DICTIONARY o}

By Joseph R. WALler, M.D., and Moritz KaAtz, M.D., revised by Dr. Braitenburg. New 7th Edition. Pp. 244. London: George Allen and Unwin Ltd. I 950 . Ios.

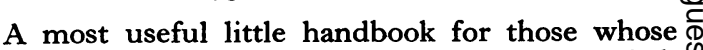
German is not entirely reliable. It is recommended. ?

A.K.M. 